\title{
Responsi Masyarakat Desa Terhadap Perkembangan Kaset Agama (Studi Kasus di Desa Datara Kab. Gowa)
}

\author{
H. Abd. Kadir Ahmad
}

I

\section{PENDAHULUAN}

Menurut Onong Uchjana Effendy, media massa merupakan media komunikasi yang mampu menjangkau khalayak yang jumlahnya relatif amat banyak, heterogen, otonom, terpencar-pencar, sertabagi komunikator yang menyebarkan pesannya bersifat abstrak. Media tersebut meliputi pers, radio, televisi, dan film, dengan cirinya yang utama menimbulkan keserempakan (simultanity) dan keserentakan (instantaneousness) pada khalayak tatkala diterpa pesan-pesan yang disebarkan kepadanya.

Alvin Toffler dalam The Third Wave (1980) membagi tiga tahap perkembangan peradaban manusia, yaitu gelombang pertama, tahap agricultural, tahap kedua, tahap industrial, dan tahap ketiga, tahap informasi, atau disebut pula gelombang ke tiga. Setiap gelombang memiliki ciri khas masing-masing, baik dalam bidang teknosfer, infosfer, sosiosfer, dan fiskosfer. Yang menjadi sumberkekuatan gelombang ketiga bukan lagi pada sumber daya alam dan pemilikan alatproduksi, melainkan terletak pada informasi sebagai kekuatan utama. ${ }^{2}$

Dalam bidang teknosfer, manusia sangat tergantung pada teknologi elektronik; dalam bidang infosfer ruang informasi tidak lagi dibatasi oleh sekat-sekat geografis lokal atau nasional, tetapi bersifat global.
Pada sosiosfer, yang menjadi agen-agen sosialisasi adalah media elektronik, menggantikan peran agen-agen sosialisasi konvensional seperti orang tua, guru dan kyai. Bahkan mass media tidak hanya berfungsi sebagai "guru" tetapi juga menjadi orang tua baru bagi jutaan anak-anak Dalam bidang fisikosfer, era informasi akan meninggalkan manusia yang bersifat magis, irrasional, dan berorientasi masa lalu. Sebaliknya muncul manusia yang lebih terbuka, berorientasi kemasa depan dan supra religius ${ }^{3}$

Hal itu sejalan dengan munculnya nilainilai modernitas, yang menurut Montgomery (1974) antara lain meliputi keterbukaan pada pengalaman-pengalaman baru, keterlepasan dari otoritas tokoh-tokoh tradisional, dan percaya kepada keampuhan ilmu pengetahuan. ${ }^{4}$

Jika pergeseran dari masyarakat tani ke masyarakat industri berlangsung selama 100 tahun, maka dari masyarakat industri ke masyarakat informasi hanya dibutuhkan waktu dua dasawarsa. Bahkan bagi masyarakat Indonesia ke tiga tahap perkembangan tersebut berlangsung sekaligus. Ketika bagian dari masyarakat belum beranjak dari era dan kultur pertanian, era dan kultur industrialisasi serta informasi sekaligus hadir dalam kehidupan mereka. Segalanya bergerak terlalu cepat. Pertanyaan yang 
kemudian muncul adalah "apakah negara berkembang seperti Indonesia tidak merasa terancam dengan masuknya nilai-nilai dan teknologi Barat?

Tampaknya, dengan era informasi itu, terjadilah apa yang disebut Georgie Anne Geyer sebagai imperialisme kultural yang merembes melalui radio dan $\mathrm{TV}$, melalui turis sampai ke negara kuno sekalipun ${ }^{5}$

Kuatnya pengaruh itu sampai-sampai TV dijuluki sebagai the fourth estate (kekuatan keempat) dan radio sebagai the fifth estate (kekuatan kelima) setelah lembagalembaga legislatif, yudikatif dan eksekutif. Bahkan, seperti kata Onong Uchjana Effendy, kecenderungan semakin meluasnya dehumanisasi, demoralisasi, bahkan desakralisasi, tidak mustahil salah satu faktornya adalah media massa itu sendiri.

Akan tetapi dalam menghadapi keadaan global seperti itu, muncul pula suatu imbalanbarudarinegara-negara berkembang : Nasionalisme Kultural. Seperti kata Naisbitt : "Di hadapan hegemonisasi yang semakin bertumbuh, kita semua akan berusaha melestarikan identitas kita, apakah itu agama, kultur, kebangsaan, bahasa, atau ras."

Dalam konteks inilah kaset-kaset bernafaskan agama ikut berperan sebagai sarana dakwah, mengimbangi kaset-kaset hiburan. Maka bersamaan dengan meningkatnya trend dunia hiburan melalui industri kaset, perkembangan baru pun terjadi, ketikauntuk kepentingan dakwah dan syi'ar Islam; ceramah, pengajian dan kasidah dikasetkan. Dan kesemarakan dakwah lewat kaset semakin populer, ketika muballigh kondang ibukota, K.H.Zainuddin MZ, masuk dunia rekaman.

Bagaimana masyarakat desa memberikan respons terhadap perkembangan dunia kaset dakwah tersebut, dan bagaimana polapola penyebaran kaset jenis tersebut dalam masyarakat desa sasaran, merupakan masalah-masalah pokok yang ditelusuri dalam penelitian ini.

Kaset disini dibatasi pada jenis kaset yang bernafaskan agama Islam, baik dalam bentuk pengajian, lagu-lagu qasidah, dan dakwah yang beredar dalam masyarakat lokal, baik yang berupa rekaman lewat rumah produksi maupun yang direkam sendiri oleh masyarakat, misalnya dari suatu pengajian, atau ceramah.

Tujuan penelitian ini adalah untuk mengetahui perkembangan lektur keagamaan lewat kaset dan respons masyarakat desa terhadap perkembangan tersebut. Dengan demikian diharapkan hasil penelitian ini dapat menjadi informasi awal mengenai penelitian lebih mendalam berikutnya, dan sebagai bahan masukan bagi pengambil kebijakan dalam pengembangan dakwah.

Penelitian dilakukan di desa Datara, Kecamatan Tompobulu, Kabupaten Gowa, Sulawesi Selatan, sebagai populasi. Sedangkan sampel ditetapkan secara purposive, dengan memilih warga masyarakat desa atau lembaga keagamaan (seperti mesjid) yang diketahui memiliki radio-tape. Dengan cara itu, didapati 16 keluarga dan 4 mesjidsebagai sampel. Selainpemilikkaset, dipilih juga sejumlah warga yang bukan pemilik sebagai sumber informasi, terutama tokoh-tokoh masyarakat dan tokoh agama. 
Teknik pengumpulan data dilakukan dengan identifikasi kaset, melakukan wawancara dengan pemiliknya dan pendengar yang lain. Pada tahap analisis dilakukan analisa isi kaset, interpretasi dan deskripsi.

\section{II}

\section{IDENTIFIKASI DAERAH PENELI- TIAN}

Desa Datara, adalah salah satu desa di Kecamatan Tompobulu, Kabupaten Gowa, Sulawesi Selatan, terletak 129 Km di sebelah selatan Ujung Pandang, dengan ketinggian 700 meter di atas permukaan laut. Desa ini berpenduduk 3,271 jiwa, 1591 laki-laki dan 1.680 wanita. semua penduduknyaberagamalslam. Luas wilayahnya 12,49 kilometer persegi, secara administratif terdiri atas 5 dusun : (1) Dusun Datara, (2) Dusun Pattong-Pattong, (3) Dusun Tonroa (4) Dusun Mampua, dan (5) Dusun Pattabbakkang.

Perekonomian penduduk bertumpu pada sektor pertanian, khususnya sub-sektor tanaman pangan padi dan jagung. Persawahan ditunjang pengairan semi teknis, yang berhulu di kaki Gunung Lompobattang, sekitar 20 kilometer dari desa itu. Melewati beberapa buah desa, sebelum sampai di Datara. Pengairan ini dari tahun ketahun semakin sering menimbulkan masalah antara petani desa-desa yang dilewati dengan desa tujuan (yang secara historis merasa lebih berhak). Meski demikian, desa ini tetap merupakan lumbung padi untuk kecamatan setempat.

Kehidupan beragama di desa ini, ditandai oleh beberapa indikator, antara lain, adanya mesjid untuk setiap dusun dan mushallah untuk setiap RK. Fungsi mesjid, selain tempat melaksanakan shalat jamaah, juga berfungsi sebagai wadah pendidikan agama, wadah informasi dan tempat musyawarah untuk membicarakan hajat orang banyak, misalnya penentuan waktu memperbaiki saluran air, kerja bakti dan sebagainya.

Fungsi mesjid yang lebih menonjol selain fungsi utamanya sebagai tempat shalat, adalah tempat pengajian dasar alQur'an, pengajian kitab, dan tilawah (tajwid dan lagu). Di Mesjid Nurul Iman Dusun Pattong-Pattong, adalah satu contoh dimana ketiga jenis pengajian itu dilakukan. Semuanya dilakukan dalam bntuk halaqah/ majlis, dimana guru dan murid duduk bersila dalam bentuk lingkaran. Metode pengajian dasar mempergunakan metode Bagdady. Waktu pelaksanaan pengajian antara Magrib dan Isya. Pengajian tradisional demikian telah membantu memecahkan pemberantasan buta aksara alQur'an bagi anak-anak. Dan dari sini, tidak jarang muncul qari/qari'ah, dan hafidz/ hafidzah al-Qur'an yang mewakili Kecamatan Tompobulu dan Kabupaten Gowa pada even-even MTQ.

Pada tahun 1987 di Desa ini didirikan sebuah Pesaritren, yang diberi nama Miftahul Ulum, tingkat Tsanawiyah dan Aliyah. Sebelumnya, anak desa setempat harus ke Malakaji dengan jarak $9 \mathrm{~km}$ untuk belajar di Madrasah. Bagi kecamatan yang jumlah sekolah agama lanjutan (Tsanawiyah dan Aliyah) tidak lebih dari lima buah, kehadiran pesantren ini dirasakan sangat membantu bukan saja masyarakat Datara tetapi juga desa-desa sekitar. Dibina 10 orang guru, dengan kualifikasi 5 orang

No. 10 Th. V Januari / Juni 1994 
sarjana muda agama, pesantren ini belajar sistem halaqah di malam hari, dan klassikal pada siang hari. Murid yang ditampung 40 orang pada tahun 1991/1992.

Suasana keterpencilan desa, tanpa hiburan bioskop, dan kesenian semacam band atau orkes, di desa ini justru berkembang kesenian Qasidah Rebana. Ada dua grup qasidah yaitu Grup Qasidah Remaja Mesjid Pangkalompo, dan Grup Qasidah Dusun Tonrowa. Keduanyaterbentuk sejak 7 tahun lalu. Selain tampil pada peringatan hari-hari besar Islam, jug tampil pada pestapesta walimah/perkawinan. Prestasi yang menonjol khususnya grup qasidah Remaja Mesjid Pangkalompo terlihat ketika untuk beberapa kali muncul sebagai pemenang festival qasidah, tingkat Kabupaten Gowa, Kotamadya Ujung Pandang sampai ke tingkat Propinsi.

Desa Datara, telah menjadi barometer keberagamaan masyarakat Islam di Tompobulu. Hal ini, antara lain, erat kaitannya dengan dekatnya hubungan emosional dan keilmuan penduduk setempat dngan K.H.Abubakar Dg Tumpu, seorang ulama kharismatik dari daerah Kabupaten Jeneponto. Kyai yang pada masyarakat setempat disebut Gurunta, merupakan guru, dan tempat rujukan masyarakat, baik dalam mengatasi masalah keagamaan maupun ketegangan-ketegangan sosial.

Ill

\section{RESPONSI TERHADAP KASET AGAMA}

Temuan kaset di Desa Datara menunjukkan variasi menurut tempat dan jenis. Tabel di bawah ini menunjukkan variasi tersebut.
Dari tabel terlihat sebaran kaset menunjukkan, jumlah kaset agama $51 \%$ dan non-

Tabel 1 : SEBARAN KASET MENURUT JENISNYA

\begin{tabular}{|c|c|c|c|}
\hline No. & Jenis Kaset & $\mathbf{F}$ & $\mathrm{F} \%$ \\
\hline 1. & $\begin{array}{l}\text { Lagu dangdut, pop, } \\
\text { daerah }\end{array}$ & 37 & 47 \\
\hline 2. & Kasidah & 12 & 15 \\
\hline 3. & Ceramah agama & 12 & 15 \\
\hline 4. & $\begin{array}{l}\text { Ceramah agama lokal } \\
\text { (rekaman) }\end{array}$ & 2 & 2 \\
\hline 5. & Mengaji & 10 & 13 \\
\hline 6. & Tarhim/adzan & 4 & 5 \\
\hline 7. & Sandiwara remaja & 1 & 1 \\
\hline & & 78 & 100 \\
\hline
\end{tabular}

agama 49\%. Akan tetapi sesungguhnya, kaset agama hanyalah bagian kecil kasetkaset yang dimiliki masyarakat. Sebab, sejak awal, para pemilik kaset umum, yang diketahui tidak memiliki kaset agama sekaligus, sengaja diabaikan dalam penelitian ini.

Sebaran kaset agama dan non agama menurut tempat dapat dilihat pada tabel di bawah ini.

Tabel : 2 SEBARAN KASET MILIK PRIBADI MENURUT DUSUN

\begin{tabular}{r|c|r|r|r|r|r}
\hline No. & $\begin{array}{c}\text { Kategori } \\
\text { Kaset }\end{array}$ & Tonroa & Datara & $\begin{array}{c}\text { Pattong- } \\
\text { Pattong }\end{array}$ & Mampua & Jml \\
\hline 1. & Ceramah & & & & & \\
2. & Agama & - & 8 & 2 & 2 & 12 \\
Kasidah & 2 & 9 & 1 & - & 12 \\
4. & Mengaji & 2 & 2 & 1 & - & 5 \\
& Non-Aga- & 17 & 11 & 10 & - & 38 \\
\hline & Jumlah: & 21 & 29 & 14 & 2 & 67 \\
\hline
\end{tabular}


Kaset agama ternyata lebih banyak beredar di dusun Datara yaitu masingmasing $67 \%$ untuk kaset ceramah agama, dan $75 \%$ kasidah, dibanding dusun-dusun lainnya. Kaset yang merupakan milik masjid terbatas pada kaset mengaji dan tarhim (salawat) dan adzan. Hal ini karena kaitannya dengan ibadah shalat.

Kecuali sebuah kaset ceramah oleh Muballig Cilik, G. Wishnu Kawirian, berjudul Mutiara Hidup, semua kaset ceramah agama yang ditemukan di lokasi penelitian adalah kaset ceramah K.H.Zainuddin, MZ, produksi Naviri Product, Jakarta. Jenis kaset Kasidah didominasi kaset Grup Kasidah Moderen Nasidah Ria; sedang pengajian adalah kaset Qari terkenal H. Muammar ZA dan Qari'ah H. Nur Asiah Jamil.

Secara keseluruhan keberadaan kaset agama di desa ini relatif terbatas. Dan sebarannya pun memiliki konsentrasi pada basis-basis tertentu dimana suasana kehidupan keagamaan lebih semarak, seperti Dusun Datara. Pemilikannya dalam suatu lokalitas pun hanya terbatas pada keluarga tertentu. Dalam satu dusun tidak lebih dari 5 keluarga.

Indikator pemilikan dan penyebaran kaset agama menyembulkan fakta adanya keterkaitan dengan faktor emosi keagamaan, latar belakang pendidikan, ekonomi, status seseorang dalam masyarakat, dan jaringan kekerabatan/professi, serta faktor lingkungan. Faktor-faktor tersebut dapat overlapping satu sama lain.

Semua pemilik kaset ceramah agama adalah mereka yang memiliki latar belakang pendidikan minimal SLTP. Dari kalangan ini tidak mesti berlatar belakang pendidikan agama, sebab ada juga berlatar belakang pendidikan umum, meski jumlahnya lebih kecil.

Fenomena pemilikan kaset kasidah juga demikian halnya. Hanya saja, syarat pendidikan tidak punya kaitan langsung dengan kepemilikan kaset jenis ini. Ratarata pemiliknya tammatan hanya tammat SD. Kondisi ini tentu saja berkaitan dengan sifat kaset kasidah yang lebih bersifat entertainment. Kemampuan menyimak makna kaset bukanlah faktor utama yang dituntut.

Peredaran kaset kasidah juga berkaitan langsung dengan kepentingan pengembangan grup kasidah itu sendiri dan pengaruh kelompok itu pada masyarakat sekitarnya. Ternyata konsentrasi peredaran kaset ini melingkar pada lokasi dimana terdapat grup kasidah. Paling tidak di tempat tersebut, Dusun Datara misalnya, telah tercipta iklim mikro seni kasidahan dimana semakin banyak orang yang terpaut dengan suasana tersebut.

Masih terbatasnya peredaran kaset ceramah agama di desa sasaran dapat dipahami dari banyak aspek. Antara lain, masih rendahnya tingkat pendidikan masyarakat, rendahnya kemampuan ekonomi, dan kurangnya jaringan popularitas kaset-kaset jenis tersebut di pasar lokal. Contohnya, di pasar Malakaji, sebagai pasar kecamatan kaset-kaset dangdut dengan mudah dapat ditemukan, tetapi kaset agama jarang.

Boleh jadi, menurut pengakuan warga, masyarakat ada yang senang dengan ceramah K.H. Zainuddin MZ karena iramanya bagus, tetapi mereka belum tentu dapat memahami maksudnya. Sama halnya, menurut warga itu, seorang Khatib yang 
mempergunakan Bahasa Indonesia dalam khutbahnya tidak diresponi jamaa, karena kurang dimengerti. Bagaikan mencangkul, katanya, lebih baik memakai cangkul sendiri.

Tetapi dalam kondisi seperti itu, ketertarikan warga desa pada jenis kaset ini sedikit demi sedikit merebak. Dan untuk menikmati sebuah kaset tidak mesti melalui jalan pemilikan. Cara lain yang dipakai mereka dalam saling meminjami, suatu tradisi yang memang lekat dengan masyarakat desa. Peredaran kaset terutama dengan cara ini mengikuti jalur sesama professi dan kekerabatan. Seorang guru SMP Malakaji, misalnya, yang memiliki beberapa seri ceramah Zainuddin MZ dapat dipinjamkan secara bergilir kepada sesama guru. Demikian juga warga desa Datara dapat saling meminjami kaset Zainuddin atau Kasidah dalam lingkar keluarga dan kerabat.

\section{IV}

\section{FENOMENA ZAINUDDIN MZ}

Suatu fenomena menarik dari hasil penelitian ini adalah, bahwa nama K.H.Zainuddin MZ tidak saja populer di kalangan masyarakat kota, tetapi juga tidak asing lagi bagi masyarakat desa, khususnya desa penelitian. Selain suaranya dapat di dengar lewat jasa radio-radio swasta yang sering "memutar" kasetnya menjelang atau sesudah shalat 5 waktu, juga lewat kasetkasetnya yang beredar di kalangan masyarakat desa. Mengapa Zainuddin?

Dalam bagian ini penulis melakukan analisis metodologis tentang ceramah Zainuddin, suatu kekhususan yang menurut penulis telah mampu menempatkan- nya dalam posisi istimewa di antara moballig lainnya di Indonesia.

Zainuddin MZ adalah sedikit dari kalangan kiyai yang memiliki kemampuan bahasa dakwah yang cukup luas. Dan salah satu faktor kemenarikan kaset-kasetnya adalah karena gaya bahasanya. Ia mampu berkomunikasi dengan semua kalangan dan lapisan masyarakat. Ketika ceramahnya bermaksud menyentuh secara lebih akrab dengan kalangan awam, ia dengan mudah mampu menggunakan dialek lokal, baik Betawi, maupun Jakarta, atau dialek lain. Tetapi ketika ingin menyentuh hati kaum remaja ia pun mampu meluncurkan bahasa froken dan pelesetan. Begitu pula ketika sasarannya kalangan birokrat dan intelektual, ia dapat menggunakan istilah-istilah asing (khususnya Inggris) yang populer di kalangan atas.

Kemampuan bahasanyajuga ditunjang oleh materi suara dan vocalnya, yang nyaring, lantang, jelas, dan berwibawa. Ia pun mampu mengatur volume dan intonasi suaranya sesuai dengan kebutuhan. Mulamula mendatar, kemudian naik, lalu mendatar lagi, sampai mencapai klimaks. Dan, ia mampu mempermainkan suaranya dalam bentuk dialog. Ia juga sering memakai gaya bahasa personifikasi, hiperboladan repetisi. Untuk menjaga konsistensi hubungan yang komunikatif dengan pendengar, ia tidak jarang melakukan pola dialog, terutama terhadap hal-hal yang membutuhkan konfirmasi, misalnya dengan pertanyaan: benar atau tidak? Jamaah menjawab : benar.

Menurut pengakuannya, sejak mengenal pidato ia gandrung kepada K.H. Idham Khalid, K.H. BuyaHamka, dan Bung 
Karno. K.H. Zainuddin M.Z. senang gaya Bung Karno. Setiap kali ada pidato Bung Karno semua kegiatan ia hentikan karena merasa ada sesuatu yang bisa menyentuh hati nuraninya. Maka iapun selalu mendengar pidato dan membaca buku karangan Bung Karno ${ }^{6>}$

Salah satu gaya dan daya tarik ceramah Zainuddin adalah kemampuannya mengekspressikan ide-idenya melalui kemasan humor yang segar. Selera humornya cukup tinggi, terbukti sepanjang ceramahnya dihiasi dengan suara gerrr dari pendengar. Hal itu dilakukan untuk menarik minat dan perhatian audiens dan menciptakan suasana informal, komunikatif dan serileks mungkin. Bedanya dengan orang lain, ia melakukan guy on tidak pernah terlepas dari konteks materi ceramah, tetapi materi itu sendiri yang dikemas dalam bentuk humor. Dengan demikian, guyonan tidak keluar dari konteks dan tidak seperti dibuat-buat.

Humor-homor Zainuddin bertumpu pada realitas, baik berkaitan dengan kehidupan remaja, rumah tangga, birokrasi, dan hubungan-hubungan sosial. Kadangkadang ia "mengeksploitasi perhatian pendengar lewat humor-homor yang sebenarnya "rawan", misalnya tentang hubungan suami isteri, muda-mudi, hubungan antar ummat beragama, hubungan pemerintah dengan rakyat, atau prilaku birokrasi. Pengungkapan dalam bentuk humor, dengan demikian, selain dimaksudkan untuk refreshing, juga memperhalus dan mengemas kritik sosial yang dianggap rawan. Hal itu, misalnya muncul ketika ia mengeritik tentang kedatangan Johannes Paulus II di Jakarta beberapa tahun lalu, etikapenyebaran agama, drama penyiksaan Masyita oleh Firaun dan sebagainya.

Sistematika ceramah Zainuddin lewat kaset secara umum memenuhi unsur suatu pidato/ceramah, yaitu pendahuluan, isi, dan penutup. Pada mukaddimahnya, ia menyebutkan topik ceramah dan tidak lupa mengaitkan topik itu dengan topik pada seri sebelumnya, jika kedua topik tersebut memiliki keterkaitan, Pada mukaddimah itu topik yang dibahas tidak selamanya diuraikan terlebih dahulu batasan-batasan dan ruang lingkupnya. Lebih sering ia langsung ke dalam inti pembahasan, sehingga arah dan skop pembahasannya memang tidak begitu terikat dan cenderung bebas. Dapat dimengerti kalau kemudian ada kesan terjadi overlapping disana-sini. Misalnya dalam memberikan contoh-contoh kasus yang dianggapnya krisis bagi ummat Islam dan bangsa Indonesia. Karena itu, jika ditilik anatomi pembahasan materi ceramah, terdapat dua bagian yaitu bagian khusus yang berkaitan langsung secara struktural dengan ide sentral yang dibahas, dan bagian yang bersifat umum, yaitu kasuskasus crusial yang perlu diinformasikan Zainuddin kepada pendengarnya, dari kalangan (segmen) jamaah Islam manapun ia berasal.

Dengan cara penyampaian seperti itu, isi kaset tidak jauh berbeda dengan ceramah populer di tablik akbar yang dikasetkan. disinilah jarak yang dibuat atau terjadi antara Zainuddin dengan kalangan pendengar yang ingin mendalami agama secara sistematis dan intelektualistik, katakanlah cendekiawan. Manakala kalangan terakhir ini juga masuk dalam kala- 
ngan penggemarnya, itu karena banyak faktor, misalnya karena keberaniannya mengungkap masalah ummat secara transparant dihadapan umum, di samping potensi pribadinya yang lain.

Dalam menguraikan suatu materi ceramah, biasanya diawali dengan mengedepankan suatu dalil (dari al-Qur'an atau Hadits) kemudian diuraikan kaitan-kaitannya dengan topik masalah. Tetapi tidak jarang juga uraiannya berangkat dari realitas kemudian dibedah dengan pisau dalil naqli. Untuk memperlihatkan aktualitas suatu kasus Zainuddin gemar mengambil fakta-fakta historis sebagai perbandingan, baik yang terjadi di masa Nabi, Sahabat, atau yang terjadi pada ummat-ummat terdahulu. Fakta-fakta historis itulah yang biasanya didramatisir aktualitasnya hingga dapat betul-betul menyentuh kasus-kasus kritis di masa kini. Langkah inipun dapat dianggap cara kritiknya yang paling jitu. Dengan sistimatika penyajian ceramah seperti itu ia menguraikan materinya dalam bentuk deskriptif, narratif, tetapi juga kadang-kadang dengan argumentatif. Dalam berupaya menjembatani antara realitas faktual dengan citra ideal ajaran Islam, Zainuddin dapat dikatakan relatif terbuka dalam memberikan penafsiran dan mempertemukan atau bahkan mempertentangkan idiom-idiom agama dengan realitas. Dengan relatif terbuka, ia dengan mudah dapat memberikan jalan keluar terhadap setiap masalah keagamaan dan sosial yang dihadapi. Hal ini pun muncul ketika ia dengan "berani" muncul dilayarperak dalam Film Nada dan Dakwah, bahkan kemudian terpilih sebagai salah satu nominator pe- meran terbaik pada Festival Film Indonesia 1992, meski kemudian ia mengundurkan diri karena alasan tidak direstui kelompok kiyai dan penggemarnya. Ia juga tidak canggung melakukan dakwah dalam gabungan kelompok artis-artis ibukota.

Kesimpulan ceramah, yang biasanya muncul pada akhir ceramah tidak selamanya dinyatakan secara eksklusif, akan tetapi lebih ditekankan pada adanya repetisi masalah yang dianggap penting dan inti. Dan repetisi itu, tidak mesti muncul di akhir ceramah.

\section{V}

\section{KESIMPULAN}

Persebaran kaset agama berjalan seiring dengan terjadinya proses transformasi masyarakat desa menjadi semakin terbuka terhadap hubungan dan pengaruh dari luar. Hal itu, antara lain didorong oleh komunikasi yang kian lancar antara kota dan desa.

Ada sejumlah faktor yang mempengaruhi respons masyarakat desa terhadap kaset agama antara lain faktor emosi keagamaan, pendidikan, ekonomi, pekerjaan dan lingkungan. Syarattertinggi dibutuhkan oleh pemilikan kaset ceramah, lebih dari kaset kasidah, dan mengaji.

Guna mengatasi keterbatasan memperoleh kaset agama, baik karena keterbatasan ekonomi atau sulit didapatkan di pasar lokal, masyarakat menempuh cara pinjam meminjam kaset antar warga, khususnya antar mereka yang seprofesi, dan memiliki hubungan kekerabatan.

Popularitas K.H. Zainuddin MZ di desa lebih dari isi ceramahnya adalah teknik penyajiannya yang karena didukung berbagai segi dirasakan komunikatif. 


\section{DAFTAR PUSTAKA}

1. Rakhmat, Jalaluddin et. al. (ed.), Keluarga Muslim Dalam Masyarakat Moderen, PT. Remaja Rosdakarya Bandung, 1993.

2. Toffler, Alvin, Kejutan dan Gelombang, PT Pantja Simpati, Jakarta, 1987.

3. Hamka, Rusydi (Penyunting), Islam dan Era Informasi, Pustaka Panjimas, Jakarta, 1989.
4. Montgomery, John D, Technology and Civic Life : Making Implementing Development Decisions, The Mit Press Cambridge, Massachusetts, and London, England, 1974.

5. Naisbitt, John dan Patricia Aburdene, Megatrends 2000, Bina Rupa Aksara, Jakarta, 1990.

6. Siregar, Evendhy M, Teknik Berpidato dan Menguasai Massa, Yayasan Mari Belajar, Jakarta, 1992. 